\title{
Strategies Required to improve Students' Industrial Training Program between Local Businesses and Technical Colleges in Enugu State, Nigeria
}

\author{
Ariyo Samson Oluwatimilehin ${ }^{1}$, Ezeda Kalu Ogbonnaya ${ }^{2}$, Sikemi Bamgboye ${ }^{3}$ \\ ${ }^{1}$ Ph.D., Department of Industrial Technical Education, University of Nigeria, Nsukka, Nigeria. \\ E-mail: samson.ariyo@unn.edu.ng
}

${ }^{2}$ Ph.D., Department of Home Economics and Hospitality Management Education, University of Nigeria, Nsukka, Nigeria. Email: ezeda.ogbonnaya@unn.edu.ng

${ }^{3}$ Ph.D., Department of Industrial Technical Education, University of Nigeria, Nsukka, Nigeria. Email: sikemiade2016@gmail.com

\begin{tabular}{l} 
Article Info \\
\hline Article history: \\
Received:15 September 2020 \\
Revised: 26 October 2020 \\
Accepted:27 October 2020 \\
\hline Keywords: \\
Technical Vocational \\
Education and Training \\
(TVET); \\
Mentoring; \\
Technical Education; \\
Technical colleges \\
JEL: I21, I28, L78. \\
Paper Type : \\
Research Article \\
\hline Corresponding Author: \\
Ezeda Kalu Ogbonnaya \\
Email: \\
ezeda.ogbonnaya@unn.edu.ng
\end{tabular}

\begin{abstract}
Purpose: The aim of the study was to identify the strategies required in improving industrial training programs between local businesses and Technical colleges in Enugu State in Nigeria.

Approach/Methodology/Design: Three Research questions and hypotheses guided the study. A descriptive survey research design was adopted for the study. The population for the study was 125 students from Government Technical College Enugu and Government Technical College in Nsukka, 23 owners of local businesses in Enugu state, 35 teachers from Government Technical College Enugu and Government Technical College in Nsukka and 10 co-coordinators from the Industrial Training Fund (ITF) Enugu State. A structured questionnaire was used for data collection. The reliability coefficiency of the instrument was found to be 0.83. Data collected were analyzed using mean for the research questions, while the null hypotheses were tested using Independent sample t-test at 0.05 level of significance.

Findings: Based on the findings, recommendations were made among which are; Local businesses should liaise with technical colleges to fashion out a suitable industrial training program that will improve students' experience. More funds should be provided by Government to improve the industrial training program.

Practical Implications: The study will contribute positively to the understanding of industrial training program in technical colleges.

Originality/value: This study innovates by suggesting strategies to improve the industrial training program between local businesses and technical colleges.
\end{abstract}

\section{Introduction}

Technical vocational education and training (TVET) is a type of education that is provided to students who wish to acquire practical skills and applied skills as well as basic scientific knowledge for the world of work (Agu, 2011). This implies that education should not only include the acquisition of knowledge but also skills aimed at achieving an all-round individual for the roles and challenges in the society. Technical and vocational education and training (TVET) is steadily gaining popularity at the global debates and government priorities for education and national development agendas (Marope et al., 2015). For Nigeria to achieve the goal of economic and technological development, technical vocational education and training 
progam needs to be improved, programs such as the industrial training program of technical colleges should be improved.

This study will determine the strategies required in improving industrial training programs between local businesses and technical colleges in Enugu State, Nigeria. Specifically, the study will determine the strategies required by local businesses, technical colleges and Government in improving the industrial training programs between local businesses and technical colleges in Enugu State. The study will be guided by the research questions that will seek to determine the strategies required by local businesses, technical colleges and Government in improving the industrial training programs of technical education. Also, hypotheses formulated will be tested to determine if there is a significant difference on the strategies required by local businesses, technical colleges and Government in improving the industrial training programs between local business and technical colleges.

\section{Literature Review}

Technical and Vocational Education Training consists of a number of interrelated fields, programmes and curricular activities with the primary objective of preparation for gainful employment. They include; Agricultural Education, Home Economics Education, Industrial Technical Education, Business and Office Education, Fine and Applied Arts Education, and Computer Education. These training areas are further broken down into different occupational trade areas as contained in the National Policy of Education (NPE) document. They include; Agricultural Production (crops and animals), Ornamental horticultures, Forestry, Catering, Garment Making, Cosmetology, Accounting and Computing occupation, Typing and related occupations, Business Data Processing Systems occupation, Personnel training, Management and related occupations, Auto mechanical occupation, Electrical and Electronics occupations, Carpentry and Woodwork, Brick laying, Crafts, Graphic arts, Sculpture, Ceramics and among others, (Federal Republic of Nigeria, 2004).

The sole aim of these occupations is meant to impart knowledge and skills for increased efficiency in the world of work, sustainable livelihoods, personal empowerment and socialeconomic development. The main objective of TVET is to develop an effectively coordinated and harmonized TVET system that is capable of producing quality skilled human resource with the right attitudes and values required for growth and prosperity in various sectors of the economy (Oyeniyi, 2012). Provision of skills and competencies is critical for the development of hands-on workers and a skilled human resource base for national development. Technical and Vocational Education Training (TVET) institutions are responsible for offering programmes that equip the graduates with quality and relevant skills and competencies to meet the needs of the labour markets. These TVET institutions are polytechnics, monotechnic, vocational enterprises and technical college. This current study will be delimited to technical colleges which constitute a part of the institutions of TVET.

Okorie (2001) explained that technical colleges in Nigeria are established to prepare individuals to acquire practical skills and basic scientific knowledge within the confinement of a technical 
institution. According to the National Board for Technical Education (NBTE) (2004), technical colleges in Nigeria are established to produce craftsmen at the craft (secondary) level and technicians at the advanced craft (post-secondary) level. The goals of technical colleges as a segment of technical and vocational education in Nigeria according to the Federal Government of Nigeria (FGN, 2004) are as follows; provide trained manpower in the applied sciences, technology and business particularly at craft and advanced craft levels; provide the technical knowledge and vocational skills necessary for agricultural, commercial and economic development and give training and impart the necessary skills to individuals who shall be selfreliant economically. The courses offered at the technical colleges lead to the award of National Technical Certificate (NTC) and National Business Certificate (NBC). Before obtaining their National Technical certificate (NTC) and National Business Certificate (NBC), students must participate in the 12 weeks Industrial training programs.

Industrial Training program in technical colleges refers to the work experience done during the program of study that is relevant to professional development prior to graduation. All technical college students in Nigeria are required to complete 12 weeks approved industrial training before graduation. This program takes place for 6 weeks at NTC 1 and another 6 weeks at NTC 2, making it a total of 12 weeks. The need for this arises as a result of global competitiveness in the industry and also the need to produce graduates of technical colleges with the skills needed in the industries in Nigeria and the world at large (Njoku, 2014). The fundamental objective of Industrial Training is to prepare students for future employment in their chosen discipline. Industrial Training enhances the academic material studied at the technical colleges by allowing students to practice what they have learned and to develop key professional attributes. Industrial training program provides an opportunity for students experience the discipline of working in a professional organization, develop understanding of the functioning and organization of a business, interact with other professional in the work place and develop technical, interpersonal and communication skills, both oral and written. The industrial training program in technical colleges in Nigeria has always made use of industries and local businesses as potential employers of technical college students embarking on their industrial training program.

Local business according to Bovarnick and Gupta (2003) refers to businesses of up to 30 people and can include household businesses, entrepreneurs and cooperatives. Cooperatives are included, although they can consist of more than 30 members, because they often face the same challenges. Local business contributes a significant portion of the National Gross Domestic Product (GDP) of many economies. According to Kehinde et al. (2016), local businesses account for a greater percentage of all businesses in virtually every economy and generate the majority of the private sector employment and output. In some developing countries, local business enterprises are the centre source of income, a breeding ground for entrepreneurs and a provider of employment (UNIDO Report, 2003). Local business enterprise constitutes a crucial component for national development for both developed nations and developing nations. Local businesses constitute a greater percentage of all the registered business in Nigeria, and they have been in existence for a long time. 
Various researches have been carried out on the Industrial Training Programme of technical education students. A study carried out by Oyeniyi (2012) on students Industrial training program concluded that if the program is improved and well implemented, it will contribute to skill acquisition significantly. Ogbuanya et al. (2018) evaluated the effectiveness of Students Industrial Work Experience Scheme (SIWES) which is similar to the industrial training programme in TVET. They observed that there exist challenges of Student Industrial training programs in providing and developing the needed skill for TVET students in the industry (Ogbuanya et al., 2018). Joseph (2017) conducted a study on industrial training programme attachment and the results revealed that the attachment of students to organizations for their industrial training programme can have an effect on the skills they will acquire for the world of work. It can be observed from various studies that industrial training program has a direct effect on the acquisition of skills by technical education students. However, despite the importance of this programme, there is brevity of literature on how to improve the industrial training programs in Nigeria. In addition, no study has investigated the role of local businesses in industrial training program. This study however will attempt to identify the strategies required in improving the industrial training program between local businesses and technical colleges.

The importance of local businesses in Nigeria to the industrial training program of technical college students cannot be overemphasized; this is because Nigeria as a developing country does not have many large industries that can assimilate all the technical college students during their industrial training. The few companies that are available often have limited spaces for training students, therefore, the majority of the students end up going to local businesses for their industrial training. The easy availability and use of local businesses to act as a place where technical college students can carry out their industrial training program has made it necessary to investigate different ways of improving the industrial training program that is been carried out by technical college students in local businesses. Therefore, it becomes important to identify the strategies required in improving industrial training program between local businesses and technical colleges in Enugu State Nigeria.

\section{Methodology and Procedures}

This study adopted a descriptive survey design. A survey research design according to Olaitan (2003) is one in which the entire population or representative sample is studied by collecting and analyzing data from a group through the use of questionnaire. The study was conducted in Enugu state in 2020. The population of the study comprised of 193 respondents. They include 125 students from Government Technical College Enugu and Government Technical College Nsukka, 23 owners of local businesses in Enugu state, 35 teachers from Government Technical College Enugu and Government Technical College Nsukkaand 10 co-ordinators from the Industrial Training Fund (ITF) Enugu State.

The instrument used for data collection was a structured questionnaire. It was developed by the researchers after review of literature. The questionnaire contains two sections, Section A and 
Section B. Section A contains items which sought to elicit the demographic information of the respondents. Section B contains 27 items on three clusters. Cluster one contains 10 items designed to find out the strategies required by local businesses in improving the industrial training programs between Local businesses and Technical colleges, cluster two contains 10 items designed to find out the strategies required by TVET institution in improving the industrial training programs between Local businesses and Technical colleges, while cluster three contains 7 items designed to find out strategies required by the government in improving the industrial training programs between Local businesses and Technical colleges. The questionnaire items were formulated based on four point rating scale. The response categories for each section were Very Highly Required (VHR), Highly Required (HR), Barely Required (BR) and Not Required (NR). The response categories were assigned numerical values of 4, 3, 2, and 1 respectively. The questionnaire was validated by one expert from the Department of Industrial Technical Education, and two experts from the Department of Home Economics, University of Enugu State. For the purpose of obtaining the internal consistency of the instrument, Cronbach Alpha reliability method was used which gave a reliability index of 0.83 .

The data collected from the study were analyzed using mean for answering the research questions and independent t-test for testing the hypotheses at probability level of 0.05 . Any item with a mean value of 2.50 and above was regarded as required while any item with a mean below 2.50 was regarded as not required. Data analyses were carried out using SPSS 22.0 as statistical packages. The statistical tools we employed are mean, standard deviation, Cronbach's alpha, Independent samples t-test. The SPSS was used to determine the mean, standard deviation, and Independent sample t-test. For the test of significance, the probability $(p)$ value was used in comparison with the alpha value of .05 , and at other relevant levels. If any item has a probability value greater than $.05(\mathrm{P}>0.05)$, it will be concluded that there is no significant difference in the mean responses of the respondents.

\section{Results and Discussion}

Table 1: Mean and t-test Analysis of the Responses on the strategies required by Local businesses in improving Industrial training program

\begin{tabular}{|c|c|c|c|c|c|c|c|c|c|c|}
\hline $\mathbf{S} / \mathbf{N}$ & Item Statements & $\mathbf{X}$ & SD & $\mathbf{X}_{1}$ & $\mathrm{SD}_{1}$ & $\mathbf{X}_{2}$ & $\mathbf{S D}_{2}$ & Sig. & $\mathbf{H}_{\mathbf{0}}$ & $\begin{array}{l}\text { Rem } \\
\text { arks }\end{array}$ \\
\hline 1 & $\begin{array}{l}\text { Industrial training } \\
\text { programs should greatly } \\
\text { expose student to relevant } \\
\text { section within the local } \\
\text { business. }\end{array}$ & 3.67 & 1.02 & 2.86 & 0.95 & 2.29 & 1.11 & 0.23 & NS & VHR \\
\hline 2 & $\begin{array}{l}\text { Expose students to more } \\
\text { equipment handling and } \\
\text { Machine operations } \\
\text { regularly. }\end{array}$ & 3.09 & 0.83 & 3.21 & 0.89 & 2.86 & 0.69 & 0.37 & NS & HR \\
\hline 3 & $\begin{array}{l}\text { Expose student to more } \\
\text { Routine Maintenance skills } \\
\text { on Machines and } \\
\text { Equipment. }\end{array}$ & 3.14 & 0.91 & 3.21 & 0.98 & 3.00 & 0.82 & 0.62 & NS & HR \\
\hline
\end{tabular}


Expose students to decision making, creative and

0.83

3.43

0.51

2.43

0.98

0.06 NS

HR

5

innovative skills.

5 Local businesses should

have positive attitudes

toward Students on

3.43

industrial training program.

6 Give full attention to

students on industrial

training program.

7 Local businesses should be

willing to accept students

for the industrial training

program.

8 Give students training

related to their areas of

specialization.

9 They should be willing to

students

$0.54 \quad 3.14 \quad 0.54$

$3.42 \quad 0.54$

0.26 NS

HR

$\begin{array}{lllllllll}3.48 & 0.68 & 3.64 & 0.50 & 3.14 & 0.90 & 0.11 & \text { NS } & \text { HR }\end{array}$

$\begin{array}{lllllllll}3.33 & 0.66 & 3.29 & 0.73 & 3.43 & 0.53 & 0.65 & \text { NS } & \text { HR }\end{array}$

10 Expose students to

technical know-how during

the industrial training

program.

Note $\boldsymbol{X}=$ Grand Mean $; \boldsymbol{S D}=$ Standard Deviation $; X_{1}=$ Male $; S D_{1}=$ Standard Deviation of Male $; X_{2}=$ Female; $S D_{2}=$ Standard Deviation of Female NS = Not Significant; VHR = Very Highly Required; HR = Highly Required; $B R=$ Barely Required; $N R=$ Not Required; $H_{0}=$ Null Hypothesis.

The data presented in Table 1 revealed that all the ten strategies have their mean value ranged from 3.09 to 3.67. This showed that the Mean value of each item was above the cut-off point of 2.50, indicating that all the strategies are required by local businesses for improving the industrial training program between Technical colleges. The table showed that the standard deviations (SD) of the items are within the range of 0.54 to 1.02 . This indicated that the mean values of the respondents were not far from one another in their responses. The table also revealed that each of the 10 sustainable strategies had a significance value ranging from 0.11 to 0.65 which was greater than 0.05 , set as the level of significance for testing the hypothesis $(\mathrm{P}>0.05)$ This indicated that there was no significant difference in the mean responses of male and female respondents on the strategies required by local businesses in improving the industrial training program between local businesses and Technical colleges. Therefore, the null hypothesis of no significant difference in the mean responses of male and female respondents on the strategies required by Local businesses in improving the industrial training program between themselves and Technical colleges in Enugu State was upheld.

Table 2: Mean and t-test Analysis of the Responses on the strategies required by Technical colleges in improving Industrial training program

\begin{tabular}{lllllllllll}
\hline $\mathbf{S} / \mathbf{N}$ & Item Statements & $\mathbf{X}$ & $\mathbf{S D}$ & $\mathbf{X}_{1}$ & $\mathbf{S D}_{1}$ & $\mathbf{X}_{2}$ & $\mathbf{S D}_{2}$ & Sig. & $\mathbf{H}_{\mathbf{0}}$ & Remarks \\
\hline 1 & $\begin{array}{l}\text { Adequate orientation of } \\
\text { students before the } \\
\text { industrial } \begin{array}{r}\text { training }\end{array}\end{array}$ & 3.33 & 0.80 & 3.57 & 0.51 & 2.86 & 1.06 & 0.08 & NS & HR
\end{tabular}




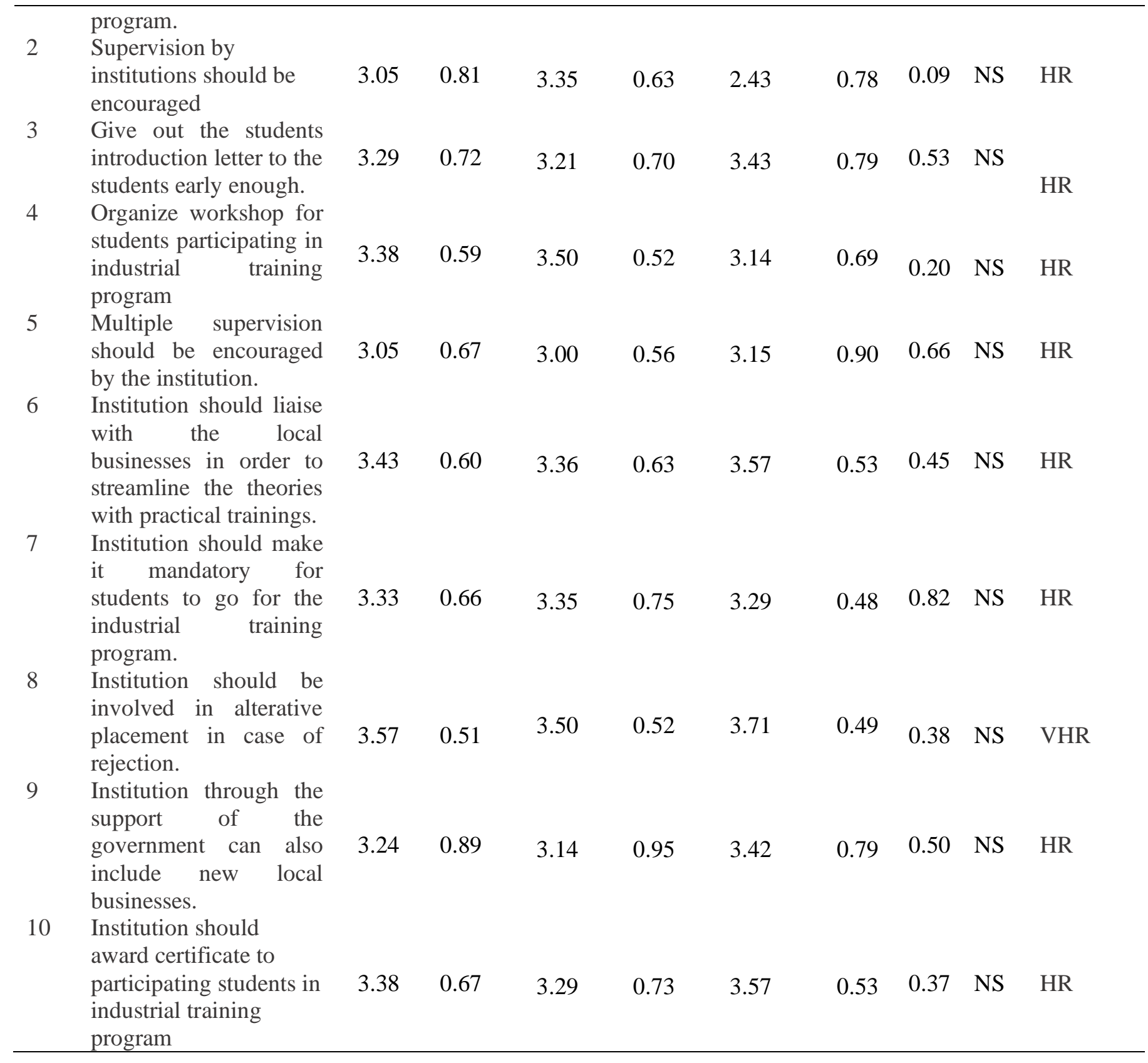

The data presented in Table 2 revealed that all the ten strategies have their mean value ranged from 3.05 to 3.57. This showed that the Mean value of each item was above the cut-off point of 2.50, indicating that all the strategies are required by Technical colleges for improving the industrial training program between them and local businesses. The table also showed that the standard deviations (SD) of the items are within the range of 0.51 to 0.89 . This indicated that the mean values of the respondents were not far from one another in their responses. Data presented in Table 2 also revealed that each of the 10 sustainable strategies had a significance value ranging from 0.08 to 0.82 which was greater than 0.05 , set as the level of significance for testing the hypothesis $(\mathrm{P}>0.05)$ This indicated that there was no significant difference in the mean responses of male and female respondents on the strategies required by Technical colleges in improving the industrial training program between local businesses and Technical colleges. 
Therefore, the null hypothesis of no significant difference in the mean responses of male and female respondents on the strategies required by technical colleges in improving the industrial training program between themselves and local businesses in Enugu State was upheld.

Table 3: Mean and t-test Analysis of the Responses on the strategies required by Government in improving Industrial training program between Local businesses and Technical colleges

\begin{tabular}{|c|c|c|c|c|c|c|c|c|c|c|}
\hline $\mathbf{S} / \mathbf{N}$ & Item Statements & $\mathbf{X}$ & SD & $\mathbf{X}_{1}$ & $\mathrm{SD}_{1}$ & $\mathbf{X}_{2}$ & $\mathbf{S D}_{2}$ & Sig. & $\mathbf{H}_{0}$ & Remarks \\
\hline 1 & $\begin{array}{l}\text { Student should be } \\
\text { motivatedbby } \\
\text { government through } \\
\text { payment of allowances. }\end{array}$ & 2.95 & 0.81 & 3.07 & 0.73 & 2.71 & 0.95 & 0.35 & NS & HR \\
\hline 2 & $\begin{array}{l}\text { Government should } \\
\text { harmonize the } \\
\text { relationship between } \\
\text { technical colleges and } \\
\text { local businesses } \\
\text { through industrial based } \\
\text { curriculum } \\
\text { implementation. }\end{array}$ & 3.09 & 0.83 & 3.09 & 0.83 & 3.14 & 0.89 & 0.86 & NS & HR \\
\hline 3 & $\begin{array}{l}\text { There should be } \\
\text { significant financing } \\
\text { commitment borne by } \\
\text { government in } \\
\text { supervising the } \\
\text { industrial training } \\
\text { program }\end{array}$ & 3.24 & 0.77 & 3.17 & 0.82 & 3.57 & 0.53 & 0.17 & NS & HR \\
\hline 4 & $\begin{array}{l}\text { Government should } \\
\text { mandate compulsory } \\
\text { supervisions of student } \\
\text { undergoing the } \\
\text { industrial training } \\
\text { program }\end{array}$ & 2.95 & 0.81 & 3.00 & 0.88 & 2.86 & 0.69 & 0.71 & NS & HR \\
\hline 5 & $\begin{array}{l}\text { Government should } \\
\text { formulate policies in } \\
\text { line with the training } \\
\text { conduct of students } \\
\text { based on the target } \\
\text { objectives of the } \\
\text { industrial training } \\
\text { program }\end{array}$ & 3.19 & 0.75 & 3.07 & 0.83 & 3.43 & 0.54 & 0.32 & NS & HR \\
\hline 6 & $\begin{array}{l}\text { Government should } \\
\text { empower the local } \\
\text { businesses used for } \\
\text { industrial training } \\
\text { program through } \\
\text { equipment and } \\
\text { materials for proper } \\
\text { skills acquisition. }\end{array}$ & 3.29 & 0.64 & 3.21 & 0.70 & 3.42 & 0.53 & 0.49 & NS & HR \\
\hline 7 & $\begin{array}{l}\text { Alternative placement } \\
\text { centers for students } \\
\text { should be created by } \\
\text { government. }\end{array}$ & 3.14 & 0.57 & 3.11 & 0.62 & 3.29 & 0.49 & 0.43 & NS & HR \\
\hline
\end{tabular}


The data presented in Table 3 revealed that all the seven strategies have their mean value ranged from 2.95 to 3.29. This showed that the Mean value of each item was above the cut-off point of 2.50 , indicating that all the strategies are required by the Government for improving industrial training program between local businesses and Technical colleges. The table also showed that the standard deviations (SD) of the items are within the range of 0.57 to 0.83 . This indicated that the mean values of the respondents were not far from one another in their responses. Data presented in Table 3 revealed that each of the seven sustainable strategies had a significance value ranging from 0.17 to 0.86 which was greater than 0.05 , set as the level of significance for testing the hypothesis $(\mathrm{P}>0.05)$ This indicated that there was no significant difference in the mean responses of male and female respondents on the strategies required by the Government in improving industrial training programs between local business and technical colleges. Therefore, the null hypothesis of no significant difference in the mean responses of male and female respondents on the strategies required by Government in improving the industrial training program between local businesses and technical colleges in Enugu State was upheld.

The findings of this study revealed that ten strategies were required by the local businesses in improving the industrial training program between technical colleges and local business in Enugu state. These findings are in agreement with the opinion of Oyeniyi (2012) who stated that if students are exposed to the right conditions during their industrial training program it will assist them in acquiring the relevant skills needed for employment. The findings of this study further revealed that ten strategies were required by the technical colleges in improving the industrial training program between local businesses and technical colleges in Enugu state. These findings are in agreement with the opinion of Ogbuanya, et.al, (2018) who observed that the institutions need to become more involved in the industrial training program of their students.

The findings of this study revealed that seven strategies were required by the Government to improve industrial training program between local businesses and technical colleges in Enugu state. These findings are in agreement with the opinion of Joseph, Gangkwi, Asukwo \& Nwibani(2017) who observed that there are different areas of industrial training program that Government needs to improve. Finally there was no significant difference on the responses of male and female respondents on the strategies required by local businesses, technical colleges and Government in improving the industrial training program. The implication of this finding is that the responses of the respondents on the strategies required by local businesses, technical colleges and Government in improving the industrial training program was not influenced by gender.

\section{Conclusion and Suggestion}

Based on the findings of the study, it can be concluded that local businesses, technical colleges and Government need to improve the industrial training program between local businesses and technical colleges. To enhance this collaboration, workshops and seminars can be organized between the main stakeholders in order to discuss together and find ways to improve the 
students' industrial training program. The study found no significant difference in the mean ratings of the respondents on the strategies required in improving the industrial training program.

Based on the findings of the study, the following recommendations were made:

1. Local businesses should liaise with technical colleges to fashion out a suitable industrial training program that will improve students' experience.

2. Workshops and seminars should be organized between local businesses and technical college industrial training program coordinators.

3. Government should provide more training centres where students can carry out their industrial training program.

4. More funds should be provided by Government to improve the industrial training program.

\section{Conflict of Interest}

The authors of the article declare no conflict of interest.

\section{Funding}

This research study was not funded by any institution. The authors conducted the study on their own expenses.

\section{References}

Agu, O. (2011). Need for Technical Education. The Truth Newspaper. November, 2011

Andrew Bovarnick and Ajay Gupta (2003). Local Business for Global Biodiversity Conservation. New York: United Nations Development Programme

Federal Republic of Nigeria (2004). National policy on education. Lagos: NERDC.

Joseph, E. B.,Gangkwi, J. H.,Asukwo, A. E. \&Nwibani, M. W. (2017) Industrial Attachment and Technical College Student Skills Acquisition forSustainable Development in Akwa Ibom State, Nigeria International Journal Of Educational Benchmark, 8 (3) 2017

Kehinde, O. J., Abiodun, A. J., Adegbuyi, O. and Oladimeji, H. (2016). Pivotal to sustainable economic development: The Nigerian experience International Journal of Current Research, 8, (1)

Marope, P.T.M., Chakroun, B. \& Holmes, K.P., (2015). Unleashing the Potential: Transforming Technical and Vocational Education and Training. UNESCO.

National Board for Technical Education (2004). National technical certificate examination (craft level) syllabus for engineering trades based on the NBTE curriculum (Ed.), Kaduna: NBTE.

Njoku, C. A., (2014). Automation in industry and curriculum review needs of mechanical engineering craft practice students in technical colleges in Lagos State. An Unpublished M.ED. Thesis University of Nigeria Nsukka. 
Ogbuanya, T. C., Njoku, C. A., Kemi, P. O. and Ogunkelu, M. O. (2018) Evaluating the effectiveness of Students Industrial Work Experience Scheme (SIWES) programme to ensure quality of technical, vocational education and training in technical colleges in Lagos State. International Journal of Vocational and technical Education, 10 (7), 6169, DOI: 10.5897/IJVTE2018.0256

Okorie, J. U. (2001). Vocational Industrial Education. Bauchi: League of Researchers of Nigeria: Bauchi.

Olaitan, S.O. (2003). Understand curriculum.Nsukka: Ndudim Publishing and Printing Company.

Onwuachu, W.C. \& Okoye, P.O. (2012). Relevance of basic science curriculum for entrepreneurship skill acquisition. Knowledge Review, 26 (4), 6-13.

Oyeniyi, A. A. (2012) Students' Industrial Work Experience Scheme (SIWES) and the Incidence of Occupational Misfit in Nigeria. Industrial Training Fund (ITF) Ibadan, Nigeria

Scott M. 2020. Vocational Training Programs/Courses ListKey Benefits. https://www.vocationaltraininghq.com/vocational-training-programs-courses-list. Retrieved 17/08/2020

UNIDO Report, 2003. Small and medium enterprise and economic development, Pakistan Journal of Business and Economic Review, 2 (1):2220-5829. 